\title{
Désiré-Magloire Bourneville and his contributions to pediatric neurology
}

\author{
Désiré-Magloire Bourneville y sus aportes a la neurología pediátrica \\ Mariana Teresa GÓMEZ-LÓPEZ', Leonardo PALACIOS-SÁNCHEZ', Alberto Vélez van MEERBEKE', Juan \\ Sebastián BOTERO-MENESES ${ }^{1}$
}

\begin{abstract}
Désiré-Magloire Bourneville ought to be thought of as the father of Pediatric Neurology for his significant contributions to the field. He worked as a physician, politician, writer, and editor. He was the first to describe the autosomal dominant genetic condition known as "tuberous sclerosis complex", after conducting an autopsy on a young female patient, where the main finding in the central nervous system was multiple dense tubers. The patient had refractory epilepsy and intellectual disability. His work was based on the study of epilepsy and idiocy, and he was also an advocate of public health and social medicine education; creating day hospital programs for children with this type of neurologic disease.
\end{abstract}

Keywords: Tuberous sclerosis; epilepsy; history of Medicine.

\section{RESUMEN}

Désiré-Magloire Bourneville debería ser considerado como el padre de la Neurología Pediátrica por sus importantes contribuciones en este campo. Trabajó como médico, político, escritor y editor. Hizo las primeras descripciones de la condición genética autosómica dominante conocida como "Complejo de esclerosis tuberosa", después de realizar una autopsia en una paciente joven, en la que el principal hallazgo en el sistema nervioso central fueron múltiples lesiones tipo tubérculos. La paciente tenía epilepsia refractaria y discapacidad intelectual como síntomas asociados. Su trabajo se basó en el estudio de la epilepsia y la idiotez, a su vez fue un defensor de salud pública y la educación en medicina social; creando programas de hospital diurno para niños con diferentes tipos de enfermedades neurológicas.

Palabras-clave: Esclerosis tuberosa; epilepsia; historia de la Medicina.

Désiré-Magloire Bourneville was a French physician, born in Garencières, Normandy on October 21, 1840 (Figure). Bourneville was a well-known neurologist who initially described tuberous sclerosis in 1880, after he noticed white "tubers" and cerebral sclerosis at necropsy in the brains of patients with epilepsy and intellectual disability ${ }^{1,2,3}$.

Very little is known about his personal life. His childhood was spent in a modest family. In his youth, he was inspired to study Medicine in Paris by a close family friend and chief of service at the Hospice de Bicêtre, Dr. Louis Delasiauve (1804-1893), who later became his mentor. He married and had a son, Marcel, an infantry sergeant, who died in hospital at age $27^{1,2}$. Bourneville's wife died before him in 1906.

Bourneville had a prolific career, as a doctor, politician, writer, and editor. After finishing his studies in Medicine in 1865 , he started working as an intern in different services.

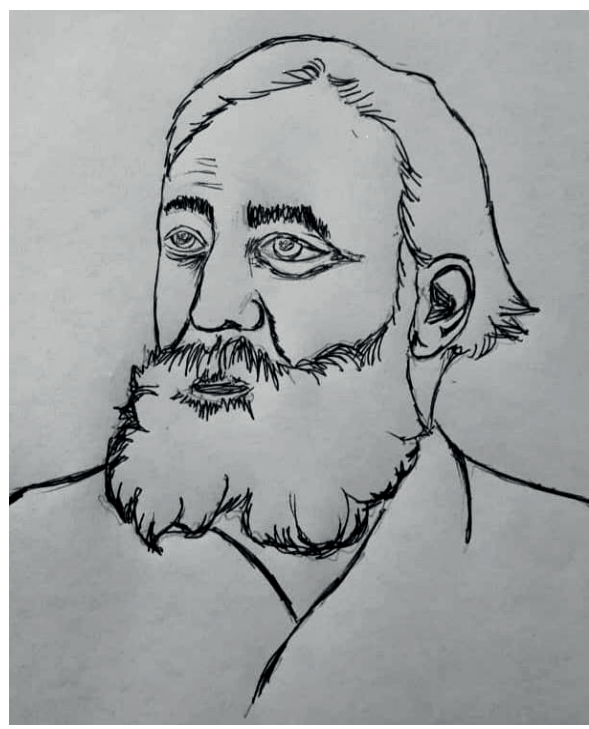

Figure. Désiré-Magloire Bourneville (1840-1909). By Jesús Gómez.

1 Universidad del Rosario, School of Medicine and Health Sciences, Neuroscience Research Group Neuros, Bogotá Colombia;

Mariana Teresa Gómez-López (iD) https://orcid.org/0000-0001-8572-9826

Correspondence: Mariana Teresa Gómez-López; School of Medicine and Health Sciences; Carrera 24 \# 63c-69, Universidad del Rosario, Quinta Mutis; E-mail: marianat.gomez@urosario.edu.co

Conflict of interest: There is no conflict of interest to declare.

Received 28 August 2018; Received in final form 28 September 2018; Accepted 01 October 2018. 
In 1868, he also worked with French neurologist, Jean Martin Charcot $^{1,2,4}$. He presented his dissertation in 1870, entitled Études de thermométrie clinique dans l'hemorragie cérébrale et dans quelques autres maladies de l'encéphale. He had profound, everlasting admiration for his two masters, who, by chance, died in the same year in $1893^{4}$.

It is important to mention that the term "medical intern" began in post-revolutionary France. However, according to the Association Amicale des Anciens Internes en Médecine des Hôpitaux de Paris, for centuries before the appearance of the terms boarding school or intern doctor, young doctors were called compagnons internes, which referred to these doctors who supported the work of surgeons and doctors in hospitals in Paris 5 .

Bourneville's political career began after the constitution of the Third Republic in $1875^{3}$. In 1876 , he was elected a city counselor in Paris; continued as a counselor in the Seine department in 1879, and culminated as a deputy in the national assembly. While in office he was a fierce advocate of health system reforms and the expansion of the hospitals in Paris, promoted global health coverage, and founded several public nursing schools ${ }^{3,4}$.

As an editor, in 1860, Bourneville collaborated with the Journal des Maladies Mentales, and La Médecine Contemporaine. In 1873, he worked on the magazine Le Mouvement Médical and founded the magazine Progrès Médical. The latter was a bulletin that published the ideas of Charcot and his school ${ }^{3,4}$.

Bourneville was also very closely involved in public health, and pioneered the opening of the first secular nursing school, which began in 1878, at La Salpêtrière Hospital. In doing so, he turned La Salpêtrière into the first school for nonreligious nurses and a multidisciplinary medical service where diseases of the nervous system were treated and managed. Bourneville's work was considered to be based mainly on idiocy and epilepsy ${ }^{1,2}$. In 1879, Bourneville was appointed head of the service of the alienated at the Hospice de Bicêtre, where epileptic patients and idiotic children were treated (by then the term idiocy referred to "little abnormal children") 4 .

Bourneville became the director of the first school for patients with intellectual disabilities. He worked in the pediatric facility at the Hospice de Bicêtre, with the title of Médecin des services d'aliénés, from 1879 to 1905 . He also created the first day school for special education for patients with intellectual disabilities and epileptic children in Paris ${ }^{3}$.

In the early $20^{\text {th }}$ century, he led a medical-pedagogical action movement that proposed that all children with any type of disability should receive education. The movement succeeded and a law was issued in 1909, which instituted reinforcement classes, in addition to those given in elementary school. The governess who taught these lessons had to be a trained nurse. All Bourneville's research papers were published in the article Recherches cliniques et thérapeutiques sur l'épilepsie, l'hystérie et l'idiotie ${ }^{3}$.

Bourneville's recognition started to fade in the early 1890s, and reached its lowest point shortly after Charcot's death in 1893. In 1905, Bourneville retired and died, isolated and impoverished, on May 28, 1909. He was cremated after a civil funeral in Père-Lachaise Cemetery in Paris ${ }^{3,46}$.

The first case of tuberous sclerosis that Bourneville attended was a 15-year-old girl named Marie. Marie had severe epilepsy, neurodevelopmental delay, and a papular eruption on her nose, cheeks and forehead. She had presented with seizures since infancy, had learning difficulties, and she could neither walk nor talk. She was treated with multiple strategies including: quinine, bromide of camphor, leeches behind the ears, and amyl nitrite. None of them seemed to work and her seizures became progressively worse. At the age of three, she was declared "a hopeless case”. Marie died in May 1879, and a postmortem study revealed dense tubers in the cerebral gyri, henceforth known as sclérose tubéreuse des circonvolutions cérébrales, determining them to be the cause of the seizures. In addition to these findings, white-colored hard masses "the size of a walnut" were found in both kidneys. Not long afterwards, in 1908, Heinrich Vogt (1875-1957) described the classic triad, that included epilepsy, mental retardation, and sebaceous adenomas ${ }^{3}$.

Today, tuberous sclerosis is known as a complex genetic condition characterized by alterations in cellular growth and differentiation, involving different systems. It is caused by a mutation of the hamartin and/or tuberin genes, TSC1 and TSC2, involving chromosomes 9 and 16 , respectively ${ }^{7}$. Tuberous sclerosis complex is a heterogeneous genetic disorder, considered to have an autosomal dominant pattern of inheritance, variable expression and complete penetrance, with mainly neurologic and cutaneous manifestations. It affects many organs such as the skin, heart, kidneys, and central nervous system. The prevalence is $1 / 5,000-10,000$ live births ${ }^{8,9}$.

Some of the main features of this disease are cutaneous signs: among them facial angiofibromas, previously known as sebaceous adenomas. These lesions were described in 1835 by Pierre Francois Olive (1793-1867). He published an atlas of illustrations where he reported a case with multiple facial erythematous angiofibromas ${ }^{9,10}$. Major and minor criteria were established by the Tuberous Sclerosis Complex Consensus Conference in 2012 (Table) $)^{8,11,12}$.

Bourneville's ideas and his deep political convictions regarding Medicine as a Social Science are very much alive to this day ${ }^{1,2,3,4}$. His care for children with physical or intellectual disability, and his strides towards ensuring adequate care for them have also become a solid contribution to Pediatric Neurology and Medicine ${ }^{4}$. 
Table. Diagnostic criteria of the tuberous sclerosis complex ${ }^{11}$.

\begin{tabular}{lc}
\hline Major features & Minor features \\
\hline Hypomelanotic macules $(\geq 3$, at least $5 \mathrm{~mm}$ diameter) & "Confetti” skin lesions \\
Angiofibromas $(\geq 3)$ or fibrous cephalic plaque & Dental enamel pits $(\geq 3)$ \\
Ungual fibromas $(\geq 2)$ & Retinal achromic patch \\
Shagreen patch & Intraoral fibromas $(\geq 2)$ \\
Multiple retinal hamartomas $(\geq 2)$ & Retinal achromic patch \\
Cortical dysplasia & Multiple renal cysts \\
Subependymal nodules & Nonrenal hamartomas \\
Subependymal giant cell tumor & \\
Cardiac rhabdomyoma & \\
Lymphangioleiomyomatosis & \\
Angiomyolipomas $(\geq 2)--$ & \\
\hline
\end{tabular}

\section{References}

1. Plantade A. Désiré-Magloire Bourneville (1840-1909). Neuropsychiatr Enfance Adolesc. 2015 Jun;63(4):268-70. 2015 https://doi.org/10.1016/j.neurenf.2015.03.003

2. Zarranz J. Bourneville: un neurólogo en acción. Neurosci Hist. 2015;3(3):107-15.

3. Paciaronia M, Cittadini E, Bogousslavsky J. Great careers: Cornil, Bouchard, Bourneville and Proust. Front Neurol Neurosci. 2011;29:61-70. https://doi.org/10.1159/000321777

4. Waverley CB. Desiré Magloire Bourneville: 21 octobre 1840 à Garancières - 29 mai 1909 à Paris. 2011 [cited 2018 Jul 30]. Available from: http://baillement.com/lettres/bourneville.html

5. Association Amicale des Anciens Internes en Médicine des Hôpitaux de Paris - AAIHP. Histoire de L'internat. Paris: AAIHP; 2004 [cited 2017 Sep 5]. Available from: http://www.aaihp.fr/ Histoire.php

6. Jansen FE, Nieuwenhuizen O, van Huffelen AC. Tuberous sclerosis complex and its founders. J Neurol Neurosurg Psychiatry. 2004;75(5):770. https://doi.org/10.1136/jnnp.2003.027524
7. Randle SC. Tuberous sclerosis complex: a review. Pediatr Ann. 2017 Apr;46(4):e166-71. https://doi.org/10.3928/19382359-20170320-01

8. Medina-Malo C, Carreño O, Vélez A, Lízcano LA, Ortiz LD, Becerra H et al. Complejo esclerosis tuberosa. Acta Neurol Colomb. 2012 Mar;28(1):11-23.

9. DiMario FJ Jr, Sahin M, Ebrahimi-Fakhari D. Tuberous sclerosis complex. Pediatr Clin North Am. 2015 Jun;62(3):633-48. https://doi.org/10.1016/j.pcl.2015.03.005

10. Acosta Garcés R, Mendizábeal Guerra R, Ayala Arcireste A, Melo Guzmán G, Padila Vázquez F, Rosas Mora I. Esclerosis tuberosa. Arch Neurocien (Mex). 2012;17(2):132-7.

11. Wilder $E$ et al. Spectrum of orocutaneous disease associations. J Am Acad Dermatol. 2017 Nov;77(5):809-30. https://doi.org/10.1016/j.jaad.2017.02.017

12. Northrup H, Krueger DA, Northrup H, Krueger DA, Roberds S, Smith $K$ et al. Tuberous sclerosis complex diagnostic criteria update: recommendations of the 2012 International Tuberous Sclerosis Complex Consensus Conference. Pediatr Neurol. 2013 Oct;49(4):243-54. https://doi.org/10.1016/j.pediatrneurol.2013.08.001 